\title{
ELECTRONIC COMMUNICATION IN THE ASPECT OF LINGUISTIC POLITENESS (BASED ON THE MATERIAL OF GERMAN LINGUOCULTURE) ${ }^{1}$
}

\author{
Rafael A. Gazizov \\ Bashkir State University, Ufa, Russia \\ Anna V. Lenets \\ South Federal University, Rostov-on-Don, Russia \\ Svetlana S. Takhtarova \\ Kazan (Volga Region) Federal University, Kazan, Russia
}

\begin{abstract}
The article presents major ways of implementing linguistic politeness in electronic communication of the German linguocultural community. Following basic communicative principles of positive politeness, the authors analyze such e-mails speech acts as greeting, appeal, parting, congratulations, wishes, gratitude, that actualize strategies of positive politeness, or strategies of reconciliation in the virtual interaction of communicants. In German linguoculture the communicative strategies of reconciliation are the attention-and-care strategy, the strategy of using in-group identity markers, the strategy of exaggeration, the strategy of giving communicative gifts, the strategy of demonstrating intense interest; their implementation is supported with various means and methods of expressiveness, including contact appeals, adjectives, pronoun viel, modal verb mögen, performative verbs of wishes and gratitude, subjunctive mood, etc. It is stated that the communicative strategies of politeness are aimed at preserving the positive face of the addressee, that is, satisfying the needs of a person to show attention, care, interest, sympathy, love towards the addressee. It should be noted that study of the principle of politeness in email writing is viewed as a priority for German linguoculture, since communication via e-mail is one of the most popular and common ways of virtual written communication both at home and in business.
\end{abstract}

Key words: electronic communication, linguistic politeness, e-mail, strategies of positive politeness, strategies of negative politeness, addresser, addressee.

Citation. Gazizov R.A., Lenets A.V., Takhtarova S.S. Electronic Communication in the Aspect of Linguistic Politeness (Based on the Material of German Linguoculture). Vestnik Volgogradskogo gosudarstvennogo universiteta. Seriya 2. Yazykoznanie [Science Journal of Volgograd State University. Linguistics], 2019, vol. 18,

\section{ЭЛЕКТРОННАЯ КОММУНИКАЦИЯ \\ В АСПЕКТЕ ЛИНГВИСТИЧЕСКОЙ ВЕЖЛИВОСТИ (НА МАТЕРИАЛЕ НЕМЕЦКОЙ ЛИНГВОКУЛЬТУРЫ) ${ }^{1}$}

\author{
Рафаэль Аркадьевич Газизов \\ Башкирский государственный университет, г. Уфа, Россия \\ Анна Викторовна Ленец \\ Южный федеральный университет, г. Ростов-на-Дону, Россия
}




\title{
Светлана Салаватовна Тахтарова
}

\author{
Казанский (Приволжский) федеральный университет, г. Казань, Россия
}

\begin{abstract}
Аннотация. В статье охарактеризованы основные способы реализации лингвистической вежливости в электронной коммуникации на немецком языке лингвокультурной общности. На материале электронных писем рассмотрены речевые акты приветствия, обращения, прощания, поздравления, пожелания, благодарности, актуализирующие стратегии позитивной вежливости, или стратегии сближения в виртуальном взаимодействии коммуникантов. Среди коммуникативных стратегий сближения наиболее распространенными в немецкой лингвокультуре являются стратегии оказания внимания и заботы, маркирования внутригрупповой принадлежности, преувеличения, дарения коммуникативных подарков, демонстрации усиленного интереса, для реализации которых использованы различные средства и приемы экспрессивизации: контактные обращения, имена прилагательные, местоимение viel, модальный глагол mögen, перформативные глаголы пожелания и благодарности, формы сослагательного наклонения и др. Выделенные коммуникативные стратегии вежливости направлены на сохранение позитивного лица адресата: удовлетворение потребностей человека в проявлении внимания, заботы, интереса, симпатии, любви по отношению к адресату. Установлено, что для немецкой лингвокультуры соблюдение принципа вежливости в письменной речи также приоритетно, как и в устной коммуникации, поскольку общение посредством электронной почты представляет собой один из наиболее востребованных и распространенных способов виртуальной письменной коммуникации как в бытовой, так и в деловой сфере.
\end{abstract}

Ключевые слова: электронная коммуникация, лингвистическая вежливость, электронное письмо, стратегии позитивной вежливости, стратегии негативной вежливости, адресант, адресат.

Цитирование. Газизов Р. А., Ленец А. В., Тахтарова С. С. Электронная коммуникация в аспекте лингвистической вежливости (на материале немецкой лингвокультуры) // Вестник Волгоградского государственного университета. Серия 2, Языкознание. - 2019. - Т. 18, № 3. - С. 162-171. - (На англ. яз.). - DOI: https://doi.org/ 10.15688/jvolsu2.2019.3.13

\section{Introduction}

Communication through electronic tools, that is, information exchange in virtual space, is getting popular in modern era of globalization and rapid development of Internet technologies. Electronic communication (also called computer-mediated communication, Internet communication, virtual communication) can be carried out either orally (via Skype, video conferencing, video calling, etc.) or in writing (using e-mail, SMS messages, messengers, forums, chats, social networks, etc.), and it has a number of features that distinguish it from ordinary speech communication (for more details on the properties and parameters of electronic communication, see: [Bergelson, 2002; Goroshko, 2012; Morozova, 2010; Trepak, 2011]).

The development of new tools and means of communication have resulted in reorganization of the way people communicate, in particular, linguists point to some evident changes in the style of interactions through e-mail, social networks, chat rooms, forums, instant messengers, which are called network etiquette (netiquette). The studies of the netiquette are in their initial stage, thus, some researchers note some variety between rules of correspondence by e-mail (E-mail etiquette) or SMS messages (SMS etiquette) [Polyakova, 2002, p. 91]. However, there are much more vital topics that require consideration. As people's communication always impose certain manners of speech behavior, the idea of speech etiquette should stay in the focus of linguistics studies. It is worth mentioning that politeness as a conversational principles is always considered vital within the framework of communication analysis, so the netiquette, a new style of electronic communications that is being shaped with the aim to regulate virtual interaction between participants, deserves special attention.

In our opinion, the study of methods for implementing electronic communication in the aspect of linguistic politeness seems to be very relevant. It should involve the analysis of communicative strategies of positive and negative politeness, which participants in virtual communication resort to ensure conflict-free interaction with each other. Researcher T.V. Larina supposes that the essence of linguistic politeness (cf. verbal politeness, sprachliche Höflichkeit) is derived from the definition of politeness as a national-specific communicative category, the 
content of which is a system of ritualized strategies for communicative behavior (linguistic and nonlinguistic) aimed at harmonious, conflict-free communication and observance of socially accepted norms in interactive communication (establishing, maintaining and completing interpersonal contact) [Larina, 2003, p. 53]. Thus, linguistic politeness may be described as a system of communicative strategies and tactics, as well as the linguistic means of verbal and nonverbal levels that help in implementation of politeness principles.

Being a system of communicative strategies and tactics, linguistic politeness in communication is aimed at preserving the face of both the speaker and the listener (addresser and addressee). The authors of the theory of face conservation P. Brown and S. Levinson suggest distinction between a positive and a negative face [Brown, Levinson, 1987]. If a positive face, according to the scientists, is associated with a desire to be respected and loved, to receive approval, sympathy, care, then the needs of a negative face, in turn, imply a person's desire to give him freedom of action and not violate the boundaries of personal space at the partner's side communications. The conversational dichotomy of the face principle by P. Brown and S. Levinson is efficiently developed in modern works. Each of the politeness types represents a certain system of communicative strategies and tactics, with the help of which the communicants strive to organize polite, conflictfree interaction with each other and then achieve their goals. For example, the strategies of positive politeness, or strategies of rapprochement (in the terminology of T.V. Larina) are aimed at demonstrating the unity and solidarity of the speaker with the listener. These politeness strategies imply the desire of the addresser to raise the positive image of the addressee by showing attention and interest in him, striving for agreement and mutual understanding with him, taking into account his inclinations and desires, creating an atmosphere of intragroup identity. In turn, strategies of negative politeness, or strategies of estrangement, are associated with the provision of freedom of action to the addressee, with the satisfaction of his need for the inviolability of personal space. They are aimed at mitigating those speech acts that could threaten a person's negative face, for example, direct requests, criticisms of the interlocutor, orders, etc.

\section{Material and subject of the research}

Having stated the general vitality of the politeness principle, we are going to consider the specificity of politeness in the netiquette of the German linguocultural community, the material for studying polite ways of virtual interaction was the e-mails. Exchanging information via e-mail is one of the most convenient ways of virtual interaction both in an informal and formal communication environment, and the analysis of verbal means of virtual communicative etiquette might reflect some specific features of politeness typical of one particular linguocultural community.

The implementation of linguistic politeness principles in electronic communication is primarily associated with the use of expressive and directive speech acts. In the e-mails of the Germans we found a frequent use of such expressive speech acts as greeting, appeal, farewell, apology, gratitude, congratulations, and wishes. Among the directives used by the Germans in electronic communication, speech acts of requests, proposals, advice, and invitation can be mentioned. If expressiveness is associated, first of all, with the strategies of positive politeness, that is, strategies for getting closer to a communication partner, then directive speech acts update the strategies of negative politeness that are necessary to express respect for the addressee and satisfy his needs for personal privacy. The scope of this article does not allow us to describe the strategies of the two types of politeness, so we restrict ourselves to one of them.

The subject of the research in this article are speech acts of greeting, appeal, farewell, congratulations, wishes and gratitude, which are thought as actualizing strategies of positive politeness.

The speech acts of greeting and appeal are being analyzed as a pair since in e-mails these speech acts are interchangeable and thereby fulfill the same functions. So, in addition to the contactsetting function, speech acts of greeting and appeal also serve to express politeness in order to strengthen the social relations of communicants not only in oral, but also in written communication.

\section{Results}

Among greeting formulae we have noted the lexeme Hallo and $\mathrm{Hi}$ in combination with the 
personal name of the addressee: Hallo Frank (Hello, Frank), Hallo Sofia, hallo Tim (Hello, Sophia, hello, Tim), Hi Olaf (Hi, Olaf). The usage of personal names within these greeting formulae expresses the strategy of rapprochement "Address by the name" and the strategy of "Use in-group identity markers", whose meaning can be conveyed by A.G. Maslou's words that any man longs for warm friendly relationships, he needs a social group to provide him with such relationships, a family to accept him as their own [Maslou, 1999, p. 86-87]. According to classification by T.V. Larina, the strategies "Address by the name" and "Use in-group identity markers" [Larina, 2009, p. 170] are the strategies of rapprochement, aimed at satisfying the need for the positive face of the interlocutor.

We have already noted that address formulae used in e-mail letters perform the same functions as greeting formulae. In informal communication addresses with the lexeme Liebe(r) are used: Lieber Wolfgang (Dear Wolfgang), Liebe Ute (Dear Ute), in formal communication - forms of address with the expression Sehr geehrte(r): Sehr geehrte Damen und Herren (Dear ladies and gentlemen), Sehr geehrter Prof. Werner Nel (Dear prof. Werner Nel), Sehr geehrte Frau Dr. Manja Hussner (Dear Madam Dr. Manja Hussner).

In German languoculture forms of address, extended with "attitude epithets" [Formanovskaya, 2005 , p. 115] as means of expressiveness and strengthening are often used. It is a well-known fact, that forms of address realize the "Give deference" strategy of politeness. According to P. Brown and S. Levinson, the authors of "saving the face" theory, this strategy is referred to negative politeness, since it objectifies reverence and respect on the part of the sender regarding the addressee. To our mind, this thesis is relevant in case of using formal forms of address, whereas in informal communication when using contact addresses the "Use in-group identity markers" the strategy of positive politeness is realized.

O.A. Vasilyeva considers the strategy of expressing deference as negative in case of using formal forms of address and as positive, if the speaker uses personal names or informal forms of address. The investigator emphasizes that as positive strategy deference in the form of address serves to satisfy the need of a person for love and respect (on the part of others), whereas as negative strategy deference is meant to emphasize a big social distance and authority degree of the addressee [Vasilyeva, 2000, p. 89]. We suppose that the notion of deference might be referred to the sphere of negative politeness, therefore while using contact addresses we should speak about the "Use in-group identity markers" strategy realization.

In e-mail letters the sender can express greetings with the help of the lexeme Gru $\beta$ after the form of address: Liebe Ute, liebe Petra und liebe Frank, hier kommt Urlaubsgruß! (lit.: Dear Ute, dear Petra and dear Frank, here come holiday regards!); Lieber Wolfgang, hier kommt ein kurzer Gruß aus Berlin (lit.: Dear Wolfgang, here comes a brief regard from Berlin). Sending the addressee positive news also enhances their positive face: Hallo Leon, Überraschung! ... ich habe schon ein Zimmer für dich (lit.: Hello, Leon, I have a surprise! ... I have already found a room for you).

It is well-known that we can express care and affection for a person by asking questions about the health of the addressee, their family, the state of things. Such questions accompany greetings: Liebe Günter, ich hoffe, es geht dir schon besser. Musst du noch weiter behandelt werden oder hat die Krankengymnastik schon genützt? (lit.: Dear Gunter, I hope, you are feeling better. Do you still have to undergo treatment or has the healing gymnastic helped?); Hallo Sofia, hallo Tim, Wie sind eure Ferien? (lit.: Hello, Sophia, hello, Tim, how is your holiday?); Liebe Lena, wie geht es dir? Wie ist Florenz? (lit.: Dear Lena, how are you? How is Florenz?); Liebe Schan, wie geht es dir in Erfurt? (lit.: Dear Shan, how are you there in Erfurt?). In these cases such strategies of positive politeness as "Notice, attend to $H$. (his interests, wants, needs, goods)" and "Intensify interest to $H$." are realized.

Within some greetings and address formulae we can use certain means and ways of expressiveness, that might denote joy in reference to meeting someody, sympathy for the interlocutor, for instance, via a performative verb sich freuen. With the help of it exaggeration strategy of positive politeness is performed: "Sehr geehrte Prüfungsbeauftragte, wir freuen uns, Sie bei 
unserem Seminar in Bonn begrüßen zu dürfen (lit.: Dear examiners, we are glad to greet you at our seminar in Bonn).

It is also noteworthy, that at present there is a tendency to simplify forms of address, i.e. to use informal forms of address in formal contexts. We can use Lieber Herr Gazizov, Hallo Herr Gazizov instead of Sehr geehrter Herr Gazizov.

German greetings and forms of address perform communication strategies of reconciliation, they are aimed at expressing consideration, sympathy, care, marking in-group identity, demonstration of intensified interest.

While greetings and forms of address mark the beginning of an act of communication, phrases of parting acknowledgement denotes its end. Via these forms partners identify the prospect of their further interaction. The choice of a certain farewell formulae at the end of electronic letters depends on the degree of intimacy, confidentiality or official character between partners in communication.

Among most frequently used formulae of greeting we have identified the lexeme Gru $\beta$ (Greetings, Regards). This component can be used mostly in the plural and in combination with the following words: 1) with the adjectives lieb, freundlich, herzlich, schön, for example: Liebe Grüße, Freundliche Grüße, Herzlichen Gruß / Herzliche Grüße, Schöne Grüße; 2) with the adjective gut in the superlative degree: Beste Grüße;3) with the indefinite pronoun viel: Viele Grüße. To intensify the degree of politeness in order to improve the positive image of the addressee the combination of the pronoun viel and the adjective lieb: Viele liebe Grüße may be applied to. The lexeme Gruß (Hello, greeting) is used most often in the plural and can be used in combination with: 1) adjectives lieb, freundlich, herzlich, schön, eg.: Liebe Grüße, Freundliche Grüße, Herzlichen Gruß / Herzliche Grüße, Schöne Grüße; 2) with the adjective gut in the superlative degree: Beste Grüße; 3) with the indefinite pronoun viel: Viele Grüße. For the sake of enhancing the level of politeness to uplift the positive image of the addressee a combination of the pronoun viel and the adjective lieb is used: Viele liebe Grüße. Some formulas are constructed with the help of the preposition mit: Mit herzlichem Gruß / Mit herzlichen Grüßen (lit.: Heartfelt greetings), Mit freundlichem
Gruß / Mit freundlichen Grüßen (lit.: With friendly greetings), Mit besten Grüßen (lit.: Best regards).

The formulas presented in the performative verb grüßen (to welcome) in combination with the adverb bestens (better, the best) are characterized by stylistically increased connotation and are used in official communication: Für Fragen stehen wir Ihnen gerne zur Verfügung und grüßen bestens (lit.: If you have any questions, we are at your disposal and would like to say Hello), Es grüßt bestens (lit.: Gladly to say hello). Compare also the use of the performative verb grüßen in the passive voice: Sei herzlich gegrüßt (lit.: Heartfelt greetings) and in combination with the adjective herzlich (heartfelt): Wir grüßen euch herzlich aus Kroatien (lit.: We give you heartfelt greetings from Croatia).

The strategy "Intensify interest to H." is expressed in the positive way by saying hello to friends and family, which is makes the addressee feels pleased: Viele liebe Grüße, auch an deine Frau-Robert (lit.: Tell hello also to your wifeRobert), Bis bald und Gruß an Mama und Papa-Bernhard (lit.: See you soon and best regards to your mom and dad-Bernhard).

The use of the addressee's personal name with the possessive pronoun dein as part of the farewell formulas marks the intragroup affiliation: Viele liebe Grüße, deine Nicole.

One of important strategies of positive politeness is "Exaggerate (interest, approval, sympathy with $H$.)". When parting it is often implemented by means of expressing wishes, which can replace the formulae of farewell, performing the function of completing a speech act in writing: Weihnachtsgrüße aus Bochum (lit.: Christmas greetings from Bochum), Ein frohes Fest und einen guten Start ins Jahr 2013 (lit.: Happy holiday and a good start in 2013). However, in many cases formulae of wishing in German e-mails complement the formulae of farewell, eg.: Schöne Gruesse und einen erholsamen Abend (lit.: Ardent greetings and pleasant evening), Herzlichen Gru $\beta$ und eine schöne Woche! (lit.: Heartfelt greetings and a wonderful week!), Liebe Grüße und schöne Ostern (lit.: Heartfelt greetings and happy Easter), Tschüß dann, bis in zwei Wochen und viel Spaß bei der Radtour! (lit.: Bye then, see 
you in two weeks and wish you lots of fun on your bike tour!).

It should be emphasized that the use of some formulae of wishes when saying goodbye in the German linguoculture, for example, Einen schönen Tag wünsche ich Ihnen (lit.: Wish You a good rest of the day), Einen erholsamen Abend (lit.: Have a relaxing evening) shows an increasing tendency to express the so-called "new German sincerity, cordiality" ("neue deutsche Herzlichkeit”) [Stephan, 1996].

Due to the fact that in writing it is impossible to use non-verbal components of communication, the addresser can verbalize, for example, hugs and kisses: Ich umarme dich, Lara (lit.: I embrace you, your Lara), Dir weiter gute Besserung und einen dicken Kuss - von deiner Sandra (lit.: Wish You further recovery and send you a strong kiss - your Sandra).

The formulas of farewell can be supplemented by verbal acts of gratitude, which increases the degree of closeness and trust between communicants, which, in turn, indicates the importance of the principle of courtesy in the German linguoculture, not only in speech communication, but also in writing: Großen Dank vorab und herzliche Grüße (lit.: First of all thank you very much and heartfelt greetings to you), Nochmals vielen Dank und freundliche Grüße (lit.: Thanks again and friendly greetings), Mit herzlichem Dank und besten Grüßen (lit.: Heartfelt thanks and kind regards), Es dankt bestens und grüßt ebenso nach Ufa (lit.: We thank you from the bottom of our hearts and also send our greetings to Ufa).

The strategies of positive politeness are also implemented through speech acts of congratulation, often in combination with speech acts of wishing that are used on the occasion of certain festive events in a person's life. It should be noted that the Germans rarely use the performative verb gratulieren (to congratulate), unlike the verb wünschen (to wish), compare congratulations:

a) Happy New Year: Ich wünsche Ihnen ein erfolgreiches und gesundes Jahr 2012 (lit.: I wish You a successful and healthy 2012), Ich wünsche Ihnen ebenfalls einen guten Rutsch ins neue Jahr 2012 (lit.: I wish You also a good new year 2012);

b) Merry Christmas: Ein erholsames, schönes Weihnachtsfest wünsche ich Ihnen (lit.: Wish You a lovely peaceful Christmas day), Ich wünsche Ihnen schon einmal eine schöne vorweihnachtliche Zeit (lit.: I wish You a wonderful pre-Christmas time now);

c) Happy Easter: Ich wünsche Ihnen allen erholsame und hoffentlich frühlingshafte Ostern (lit.: I wish You all a quiet and spring Easter).

In some cases the verb wünschen may be omitted: Ein frohes Fest und einen guten Start ins Jahr 2013 (lit.: Happy holiday and a good start in 2013), Einen guten Rutsch ins neue Jahr! (lit.: Happy meeting the New year!).

Congratulations and wishes can also be used in a pair with the formulae of farewell, for example:

a) Happy New year greeting: Viele Grüße und noch alles Gute für 2016! (lit.: With friendly greetings and all the best in 2016!);

b) Easter greetings: Liebe Grüße und schöne Ostern (lit.: Send you friendly greetings and wish happy Easter);

c) wishes in everyday life: schöne Gruesse und einen erholsamen Abend (lit.: Send you my friendly greetings and wish a relaxing evening!), Einen schönen Tag wünsche ich Ihnen und verbleibe mit herzlichen grüßen (lit.: I wish You a good day and convey my heartfelt greetings).

The following examples of wishes are used instead of formulae of farewell, like the wishes for the weekend: Ich wünsche Ihnen trotz allem ein erholsames Wochenende (lit.: I wish You despite everything a relaxing weekend), Ich wünsche Ihnen ein schönes und hoffentlich sommerliches Wochenende (lit.: I wish You a wonderful and, I hope, summer weekend), Bis dahin wünsche ich Ihnen ein schönes Wochenende (lit.: Until then, I wish You a wonderful weekend). In this case, the strategy of positive politeness is aimed at demonstrating care to the partner in electronic communication, so that he can have a good rest during the weekend and gain strength.

Wishing successful performance of tasks, and also readiness of the addresser to answer questions of the partner along with the abovedescribed forms of the wish are the next means of implementation of the "rendering attention and care" strategy: Ich wünsche Ihnen einen reibungslosen Prüfungsverlauf (lit.: Wish You a coherent / systematic examination); Wir 
wünschen Ihnen eine erfolgreiche Durchfuehrung der Pruefung (lit.: We wish You a successful exam); Alles Gute, Fragen aber wie immer gern. Herzlichen Gruß (lit.: All the best, I'm eager to answer the questions. With cordial greetings).

The strategy of politeness is actualized also with the help of formulae of wishing, combined with the formulae of gratitude: Schon jetzt danken wir Ihnen herzlich für ihr Engagement und wünschen Ihnen ein schönes Weihnachtsfest und ein glückliches und gesundes Jahr 2013! (lit.: Right now we thank You sincerely for Your work and wish You a wonderful Christmas and a happy, healthy 2013!); Wir danken Ihnen und wünschen eine erfolgreiche Testdurchführung (lit.: We thank You and wish you a successful exam); Vielen Dank für Ihre Unterstützung und ein schönes Wochenende (lit.: Thank you very much for Your support and wish You a wonderful weekend). In the first example, the addressee increases the degree of gratitude through the adjective herzlich (cordially), while actualizing an exaggeration strategy that is aimed at demonstrating increased interest in his communication partner.

It should be noted that the use of the formulae of congratulations and wishes in e-mails is limited by the possibilities of written speech, in which the implementation of such types of communicative etiquette as table and occasional etiquette may be marked with a certain formulae of congratulations and wishes. On the contrary, greetings and wishes are widely used in different types of communication etiquette, including festive, table, diplomatic, business etiquette, etc.

Among the communicative strategies of positive politeness in e-mails Germans often use the strategy of "Give gifts to H. (goods, sympathy, understanding, cooperation)" or the strategy of giving communicative gifts. The point of this strategy of rapprochement is to express a benevolent attitude, sympathy, disposition to the interlocutor. As well as the strategy of giving attention, concern and interest, this politeness strategy is aimed at enhancing the positive image of the addressee, meeting the needs of his positive personality. While in verbal communication for the implementation of this strategy apart from the verbal means, non-verbal communication components are widely used (smile, embrace, handshake, kiss, etc.), in e-mails the strategy of giving communicative gifts is most often realized via gratitude formulas. Although in electronic communication, in particular, when communicating on social networks, instant messengers, using text messages, WhatsApp, etc., non-verbal components of communication are widely used in the form of emoticons, or socalled "emojis", expressing certain emotions and actions.

As it is well-known, one of the most common forms of gratitude expression in the German linguoculture is the speech act Danke!, used in both formal and informal communication settings. As a rule, this gratitude formula in German emails can be extended with the help of:

a) adjectives schön, herzlich, gro $\beta$ : Dankeschön (lit.: Thank you very much), Herzlichen Dank fuer Ihre Unterstuetzung (lit.: Warm thanks for your support), Großen Dank vorab und herzliche Grüße (lit. Thanks a lot in advance and cordial greetings);

b) the pronoun viel: Vielen Dank im Voraus für Ihre Antwort (lit.: Thank you very much in advance for your reply).

Many formulas of gratitude, as well as forms of greeting, farewell, apology, etc. are desemantized and clichéd, which confirms their frequent use in the communicative behavior of the German linguocultural community. The semantic emptiness of many German formulas of speech etiquette caused the use of some strengthening markers in their composition, by which such a strategy of positive politeness as the strategy "Exaggerate (interest, approval, sympathy with $H$.)", or the strategy of exaggerating interest and sympathy with a communication partner is implemented. Thus, among politeness intensifiers, we can distinguish:

a) the adjective gut in the superlative degree: Es dankt bestens und grüßt ebenso nach Ufa (lit.: We gladly thank you and send best regards to $U f a$ );

b) adverbs ganz and sehr: Ganz herzlichen Dank für Ihre freundlichen Worten (lit.: Heartfelt gratitude for your kind words); Wir würden uns freuen, wenn Sie wieder so erfolgreich Werbung machen würden und danken Ihnen schon jetzt sehr herzlich! (lit.: We would be glad if you could hold such a 
successful advertising campaign again and we thank you now wholeheartedly!);

c) the pronoun viel in combination with the adjective herzlich: Vielen herzlichen Dank für Ihre freundliche Antwort (lit.: Many heartfelt thanks for your friendly reply);

d) repeated gratitude: Nochmals vielen Dank und freundliche Grüße (lit.: Thanks again, and friendly greetings).

In many cases thank-you formulas with empty semantics are used, as a rule, they are formal markers of politeness, or peculiar communicative gifts [Larina, 2009, p. 342], the following formulas are used as a sign of gratitude for the service actually provided:

a) using performative verbs danken and sich bedanken (to thank): Schon jetzt danken wir Ihnen herzlich für Ihre Unterstützung! (lit.: Already we thank you for your support!); Über eine Rückmeldung bedanke ich mich im Voraus (lit.: I thank you in advance for your reply);

b) especially in combination with the adjective herzlich in the function of an adverbial modifier: Ich ... danke Ihnen ganz herzlich für die gute Zusammenarbeit in den letzten Jahren (lit.: I sincerely thank you for your close cooperation in recent years).

In the following example, the addresser refers to a double form of gratitude: So kann ich Ihnen danken: Vielen, vielen Dank! Ich bin so froh! (lit.: So I can thank you: thank you very much! I am so glad!). Such forms of gratitude increase the degree of politeness of etiquette units and thereby implement the strategy of exaggerating interest and sympathy.

Another method of intensification and enhancement that help in realizing the strategy of exaggeration, is the use of modal verbs in the composition of thank-you formulas, cf. the use of the verb mögen: Wir möchten uns für Ihren Beitrag bedanken (lit.: We would like to thank you for your report), Ich möchte mich nun sehr gern persöhnlich bei Ihnen bedanken und Ihnen auch einen Finderlohn geben (lit.: I would like to thank you personally and give you reward for finding). It should be noted that the verb mögen is used exclusively in the subjunctive mood, since in the indicative it has the meaning "to like, to love". According to R.Z. Muryasov, the status of the verb mögen is the most speculative. The researcher points out that the
Preterit form in the conjunctive of this verb möchte should be recognized as an independent verb, because like the English modal verb might (from may) it is deprived of a temporal meaning and expanded by the pragmatic connotation of diplomacy and politeness [Muryasov, 2011, p. 253].

\section{Conclusion and perspectives}

Thus, in the German linguoculture, communication via e-mail is one of the most common and convenient ways of virtual written communication in both casual and business fields. Compliance with the principle of politeness through the use of communicative strategies is aimed at regulating harmonious, conflict-free communication, during which communicators achieve their goals. In the German linguoculture adherence to the principle of politeness in communicative interaction of interlocutors is a priority both in verbal communication and in written speech.

The identified and analyzed strategies of positive politeness used by the Germans in electronic correspondence are aimed at expressing interest, sympathy, caring for the addressee, i.e. maintenance of his positive personality. In the German linguoculture, relating to the individualistic type, such cultural values as independence, personal autonomy, non-interference, and inadmissibility of communicative pressure are especially revered. In turn, as the research revealed, equally important are the need to express a friendly and respectful attitude towards a communication partner, expression of attention, sympathy, care and interest in him, marking an intra-group affiliation, and demonstrating increased interest, which is possible through the use of strategies of positive politeness.

It appears to be promising to study ways to implement strategies of negative politeness aimed at meeting the needs of a negative face, as well as to study the functioning of the principle of politeness in other forms of electronic communication.

\section{NOTE}

${ }^{1}$ The reported study was funded by RFBR, project number 18-012-00226 A "Modeling of the 
Influence of Social Processes on the Formation of Linguistic-Cultural Constants of the Modern GermanSpeaking Space of Europe and Optimizing Intercultural Communication".

\section{REFERENCES}

Bergelson M.B., 2002. Yazykovye aspekty virtualnoy kommunikatsii [Language Aspects of Virtual Communication]. Vestnik Moskovskogo gosudarstvennogo universiteta. Seriya 19, Lingvistika i mezhkulturnaya kommunikatsiya [Bulletin of Moscow University. Series 19. Linguistics and Intercultural Communication], no. 1, pp. 55-67.

Brown P., Levinson S.C., 1987. Politeness: Some Universals in Language Usage. Cambridge, Cambridge University Press. 345 p.

Formanovskaya N.I., 2005. Emotsii, chuvstva, intentsii, ekspressii v yazykovom i rechevom vyrazhenii [Emotions, Feelings, Intentions, Expression in Language and Speech Expression]. Sharonov I.A., ed. Emotsii v yazyke $i$ rechi: Sbornik nauchnykh statey [Emotions in Language and Speech. Collection of Scientific Articles]. Moscow, RGGU, pp. 106-116.

Goroshko E.I., 2012. Sovremennaya internetkommunikatsiya: struktura i osnovnye parametry [Modern Internet Communication: Structure and Main Parameters]. Kolokoltseva T.N., Lutovinova O.V., eds. Internet-kommunikatsiya kak novaya rechevaya formatsiya: kollektiv. monogr. [Internet Communication as a New Speech Formation. Collective Monograph]. Moscow, Flinta Publ., Nauka Publ., pp. 9-52.

Larina T.V., 2003. Vezhlivost kak natsionalnospetsificheskaya kommunikativnaya kategoriya [Politeness as a National-Specific Communicative Category]. Sternin I.A., ed. Kommunikativnoe povedenie. Vyp. 17. Vezhlivost kak kommunikativnaya kategoriya [Communicative
Behavior. Iss. 17. Politeness as a Communicative Category]. Voronezh, Istoki Publ., pp. 48-57.

Larina T.V., 2009. Kategoriya vezhlivosti $i$ stil kommunikatsii: Sopostavlenie angliyskikh $i$ russkikh lingvokulturnykh traditsiy [Category of Politeness and Communication Style: Comparison of English and Russian Linguistic and Cultural Traditions]. Moscow, Yazyki slavyanskikh kultur Publ. 512 p.

Maslou A.G., 1999. Motivatsiya i lichnost [Motivation and Personality]. Saint Petersburg, Evraziya Publ. $478 \mathrm{p}$.

Morozova O.N., 2010. Osobennosti Internetkommunikatsii: opredeleniye i svoystva [Features of Internet Communication: Definition and Peculiarities]. Vestnik Leningradskogo gosudarstvennogo universiteta im. A.S. Pushkina [Vestnik of Pushkin Leningrad State University], vol. 1 , no. 5, pp. 150-158.

Muryasov R.Z., 2011. Tipologiya glagola $v$ raznostrukturnykh yazykakh [Verb Typology in Structurally Different Languages]. Ufa, RICz BashGU. 328 p.

Polyakova O.Yu., 2002. Delovoy etiket v upravlenii vpechatleniem [Business Etiquette in the Management of the Impression]. Moscow, Voronezh, Kvarta Publ. 320 p.

Stephan C., 1996. Neue deutsche Etikette [New German Etiquette]. Reinbek bei Hamburg, Rowohlt Taschenbuch Verlag GmbH. 159 p.

Trepak Ya.V., 2011. Osnovnye kharakteristiki elektronnoy kommunikatsii [Basic Characteristics of Computer-Mediated Communication]. Vestnik Moskovskogo gosudarstvennogo oblastnogo universiteta. Seriya: Lingvistika [Bulletin of the Moscow Region State University. Series: Linguistics], no. 3, pp. 83-89.

Vasilyeva O.A., 2000. Realizatsiya maksim vezhlivosti v angliyskom i russkom dialogakh: dis. ... kand. filol. nauk [Implementation of the Maxims of Politeness in English and Russian Dialogues. Cand. phil. sci. diss.]. Ufa. $158 \mathrm{p}$.

\section{Information about the Authors}

Rafael A. Gazizov, Doctor of Sciences (Philology), Associate Professor, Dean of the Faculty of Romano-Germanic Philology, Bashkir State University, Kommunisticheskaya St., 19, 450076 Ufa, Russia, fund-lingua@rambler.ru, tasufa.gazizov@gmail.com, https://orcid.org/0000-0003-1391-5288

Anna V. Lenets, Doctor of Sciences (Philology), Associate Professor, Head of the Department of German Philology, South Federal University, Bolshaya Sadovaya St., 33, 344082 Rostov-on-Don, Russia, annalenets@sfedu.ru, annalenets@mail.ru, https://orcid.org/0000-0002-7394-3259

Svetlana S. Takhtarova, Doctor of Sciences (Philology), Associate Professor, Head of the Department of Theory and Practice of Translation, Kazan Federal University, Kremlyovskaya St., 18, 420018 Kazan, Russia, sstahtarova@kpfu.ru, teor.prakt.per@kpfu.ru,https://orcid.org/0000-0002-9268-6892 
R.A. Gazizov, A.V. Lenets, S.S. Takhtarova. Electronic Communication in the Aspect of Linguistic Politeness

\section{Информация об авторах}

Рафаэль Аркадьевич Газизов, доктор филологических наук, доцент, декан факультета романо-германской филологии, Башкирский государственный университет, ул. Коммунистическая, 19, 450076 г. Уфа, Россия, fund-lingua@rambler.ru, tasufa.gazizov@gmail.com, https:/orcid.org/0000-0003-1391-5288

Анна Викторовна Ленец, доктор филологических наук, доцент, заведующая кафедрой немецкой филологии, Южный федеральный университет, ул. Большая Садовая, 33, 344082 г. Ростов-на-Дону, Россия, annalenets@sfedu.ru, annalenets@mail.ru, https://orcid.org/0000-0002-7394-3259

Светлана Салаватовна Тахтарова, доктор филологических наук, доцент, заведующая кафедрой теории и практики перевода, Казанский (Приволжский) федеральный университет, ул. Кремлевская, 18, 420018 г. Казань, Россия, sstahtarova@kpfu.ru, teor.prakt.per@kpfu.ru, https://orcid.org/0000-0002-9268-6892 